\title{
Geographic races may exist among perennial grasses
}

Theodore E. Adams J Charles E. Vaughn J Peter B. Sands

\begin{abstract}
California's native perennial grasses have been largely replaced by alien annuals. Interest in restoration of native grasslands is strong, but genetic differences among the available collections of some grasses may affect the survival of plantings and remnant native stands. In collections of the four native grasses examined, differences in phenology, growth form and forage quality suggest the existence of geographic races.
\end{abstract}

The degradation of California's native perennial grasslands and concurrent invasion by alien annuals have resulted in a type-conversion throughout much of the prairie biome (Dassman 1973, Menke 1989). Native grasses are not known to be extinct, but with few exceptions they are not dominant anywhere. The growing interest in restoration ecology and the documented value of perennial grasses for several uses, both extensive and intensive, have encouraged the planting of these grasses. However, lack of knowledge concerning important differences within species is a major problem. Many plantings are being made with collections that may represent poorly adapted genotypes, and these could fail to persist and weaken the remnants of local gene pools (Millar and Libby 1989; Fenster and Dudash 1994; Knapp and Dyer 1997).

This study was conducted to examine potential differences in production and quality in several collections of four important California native perennial grasses and to determine whether distinct geographic races exist.

We conducted the study at two sites in different climatic regions representing typical open grasslands now domi- nated by exotic annuals. The driest site, Hedgerow Farms in Yolo County, receives about 22 inches of rainfall each year (based on weather records maintained in the nearby town of Winters). At the second site, the UC Hopland Research and Extension Center in Mendocino County, average annual precipitation (snow falls in some winters) is about 37 inches, nearly $70 \%$ greater. The average monthly temperature at Hedgerow is $62^{\circ} \mathrm{F}$ compared with $57^{\circ} \mathrm{F}$ at Hopland.

\section{Seventeen collections planted}

We planted nursery-propagated seedlings of four native California bunch grasses and one introduced bunch grass, representing 17 accessions (collections), in late winter 1992 1993 at the two sites (fig. 1). The seedlings at each site were exposed to the same environmental conditions in what is called a "common garden." The seedlings were propagated commercially by Valley Transplant Co. of Acampo. The species represented were blue wildrye (Elymus glaucus), three accessions; California melic (Melica californica), three accessions; nodding needlegrass (Nassella cernua), four accessions; and purple needlegrass ( $N$. pulchra), six accessions. Berber orchard grass (Dactylis glomerata), a perennial native to North Africa and recommended for range plantings in California's Mediterranean-like climate, was the exotic included for comparison.

Four of the seven counties of origin for the native accessions are representative of the hot Central Valley: Tehama, Colusa, Yolo and Kern. The
Fig. 1. Counties of origin for accessions of native perennial grasses studied and the two planting sites, UC Hopland Research and Extension Center and Hedgerow Farms.

climates of Marin, Solano and Santa Clara counties are moderated by a marine influence, and Lake County in the Coast Range is more moist than the interior (fig. 1).

We planted accessions in randomized complete blocks with harvest dates as a repeated measure. The 56 seedlings in each plot were spaced on 6-inch centers with four replications. Plantings were maintained weed free and allowed to develop for one season. Beginning in March 1994, we harvested 10 plants each during three 11to 20-day periods ending in June. Extended periods for harvest were necessary to accommodate the delay in development between the Hedgerow (harvested first in each period) and Hopland sites.

At Hedgerow, we periodically recorded changes observed in the plantings during the growing season and on harvest dates. During the last harvest at Hedgerow, we estimated mature height. Resources did not permit capturing these data at both locations.

To assess production and quality, we measured aboveground biomass (expressed in pounds per acre, airdry), percentage nitrogen, percentage acid detergent fiber and percentage neutral detergent fiber. Dried wholeplant samples were prepared for 

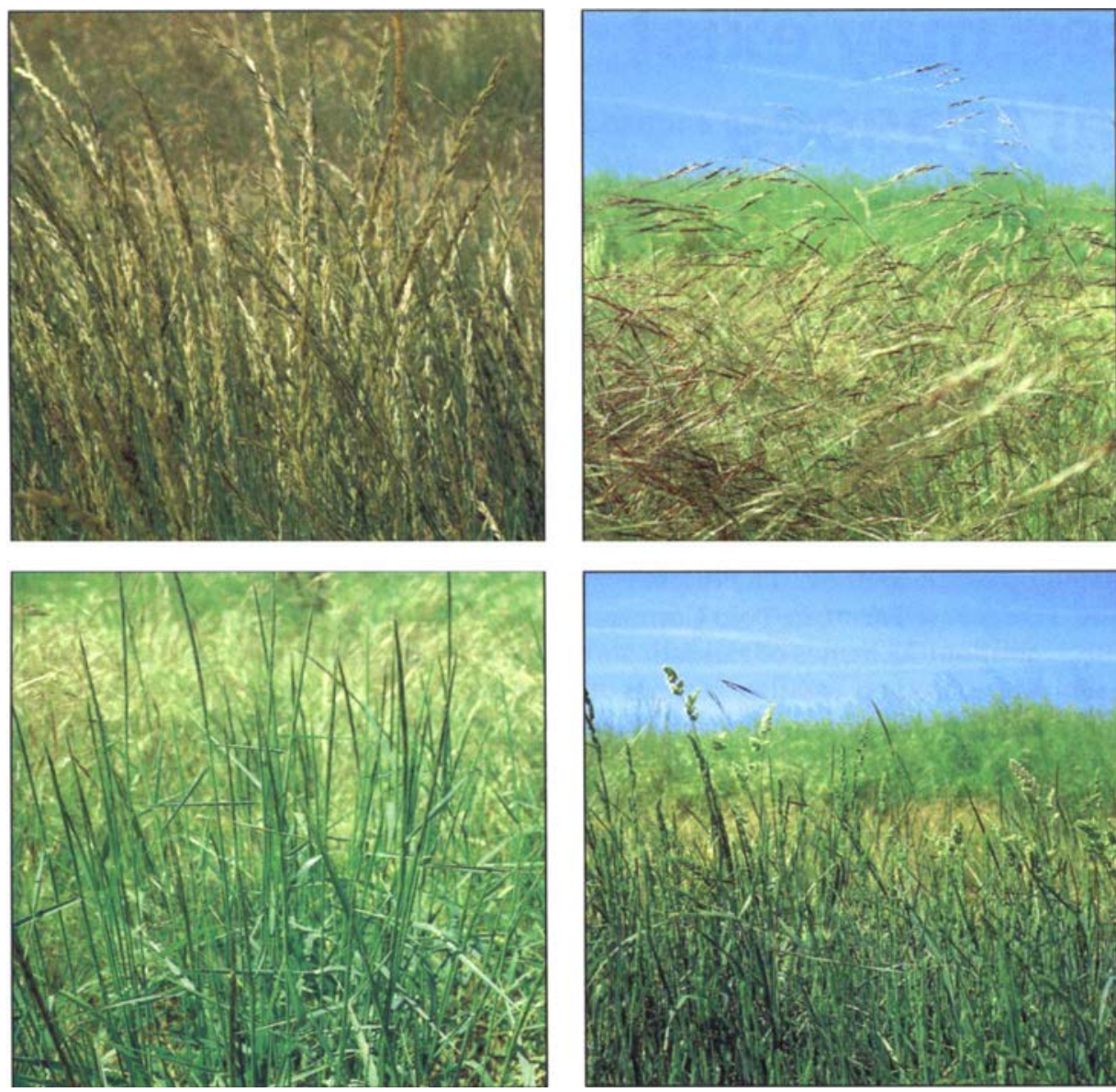

Clockwise from top left: California melic, needlegrass, Berber orchardgrass and blue wildrye.

chemical analysis by grinding in a Wiley mill, then oven-drying. Percentage nitrogen is reported as percentage crude protein $(\mathrm{PCP})$ calculated using percentage nitrogen times the factor 6.25 .

The properties measured are of interest to a spectrum of resource managers. Chemical constituents were chosen because of their influence on the nutrition of range livestock and wildlife and the need to express potential differences in terms of forage value. Large and small wild herbivores and other wildlife are affected by both the amount and quality of groundcover.

Data for production and quality parameters were subjected to a split-plot, repeated measures Analysis of Variance (ANOVA) at both locations. Unless otherwise noted, differences in performance among accessions were separated at the $99 \%$ level of confidence $(P \leq 0.01)$ by Fisher's protected least significant difference (LSD) to in- sure a conservative interpretation of results.

Both production and quality, as measured in this study, identify information captured at intervals not keyed closely to the growth stages of individual accessions. However, the procedure does permit the identification of potential differences in performance related to time. Periodic harvest was necessary because resources were limited and did not permit a more precise (and intensive) procedure keyed to the phenology of individual accessions.

\section{Height, seasonal growth changes}

The most common height of the mature native grass accessions was 85 inches (table 1). The Berber orchard grass was also 85 inches tall.

Seasonal growth changes (phenology) among accessions reaching late maturity demonstrated water stress due to the low rainfall in 1993-1994, which was $70 \%$ less than expected. Rainfall at Hopland during this time was $65 \%$ of expected. Several needlegrass accessions that had not completed the reproductive cycle before the last harvest possessed unfilled seeds (caryopses). Heads of Berber orchard grass, the species which completes its reproductive cycle most slowly, produced mostly dry heads with no seed.

Accessions in three of the four native species showed significant $(\mathrm{P} \leq$ 0.05 ) differences in mature height; only those of nodding needlegrass were not different. The Tehama County collection of blue wildrye was different from the others and $50 \%$ taller than the one from Marin County. In the California melic group, the Lake County collection was different and about $20 \%$ taller than the Tehama County collection. Among the purple needlegrasses, stem elongation was $25 \%$ greater in the accession from Colusa County. For this group, stem elongation better describes growth than does height, because the Marin County accession began to lie down as it grew.

\section{Differences among accessions}

The differences among accessions were compared in terms of forage production (table 2), percentage crude protein (PCP) (table 3), percentage acid detergent fiber (ADF) (table 4) and percentage neutral detergent fiber (NDF) (table 5). Since accessions were grown in common gardens, we assumed the differences measured represent genetic differences influenced by environmental conditions where collections were made.

Blue wildrye. Santa Clara County was highest in production but lower in PCP than Tehama, and Marin retained its PCP longer into the season than did the other two. Tehama County was lowest in ADF but in the last harvest it had the most NDF. And Tehama's average NDF at Hedgerow was higher than that of the other two but lower at Hopland. The NDF values for Santa Clara and Marin were the lowest of all native grass accessions at Hedgerow, but between sites no other accessions displayed a greater difference. 
California melic. Lake County was the most productive, but Tehama was highest in PCP and retained it better at maturity. Tehama was also lowest in $\mathrm{ADF}$ and NDF, and with the three accessions of blue wildrye it shared the lowest average NDF among all the accessions of native grass.

Nodding needlegrass. Solano and Tehama counties were more productive at Hedgerow than at Hopland. At Hedgerow, Kern County did not reach maximum production until the third harvest, while Kern and Solano counties were the most productive in the third harvest. At Hopland, Solano did not reach peak production until the third harvest; it followed the pattern of production exhibited by Kern at Hedgerow.

As accessions matured, the pattern of PCP decline was different for two accessions at Hedgerow: both Solano and Yolo counties retained forage quality longer and did not decline significantly between harvests one and two.

Purple needlegrass. The average productivity of accessions from "dry" counties - Colusa, Tehama and Yolo - was nearly $40 \%$ greater than that of accessions from "moist" counties Lake, Marin and Solano. At Hopland, Marin and Solano counties lagged in second-harvest production.

Compared with "dry" accessions, those from "moist" counties were $10 \%$ higher in PCP and lower in ADF and NDF by $5 \%$ and $3 \%$, respectively.

\section{Natives vs. orchard grass}

Forage production. Berber was nearly $80 \%$ more productive at Hedgerow than at Hopland (table 2), and at Hedgerow it was $50 \%$ more productive than the average of seven native accessions: Tehama blue wildrye, California melic from Yolo and Tehama counties, the Kern and Tehama county accessions of nodding needlegrass, and two accessions of purple needlegrass, Lake and Solano counties.

Differences in production at Hopland were smaller, and both Santa Clara blue wildrye and Colusa purple needlegrass were $50 \%$ more productive than Berber.
At Hedgerow, Berber was $50 \%$ more productive in the third harvest than the second, 8,600 pounds per acre vs. 5,600 pounds per acre, but no difference $(P \leq 0.05)$ between harvests occurred at Hopland, where the average was 3,900 pounds per acre.

Percentage crude protein (PCP). At Hopland, orchard grass was at least
$15 \%$ lower in PCP than Tehama California melic and three accessions of needlegrass, Tehama nodding needlegrass and Solano and Marin purple needlegrass (table 3 ). At Hedgerow, PCP in two accessions, Solano nodding needlegrass and Marin purple needlegrass, was $13 \%$ to $16 \%$ higher than orchard grass.

TABLE 1. The 1994 phenology at 3 harvests and the mature height of 16 accessions of California native bunch grasses and Berber orchard grass at Hedgerow Farms and a height:weight ratio for each accession expressed in pounds:inch using average seasonal production at Hedgerow Farms

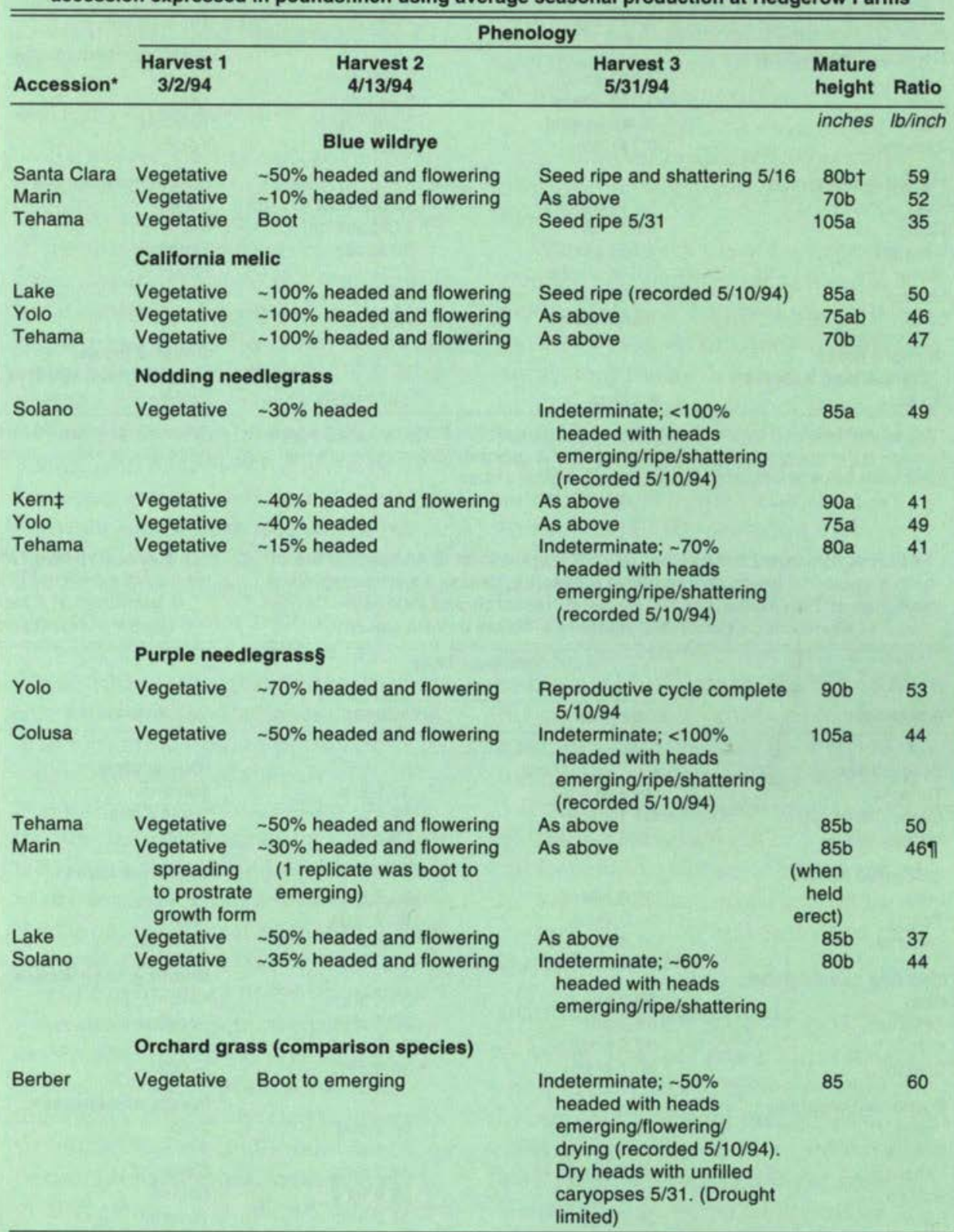

"The natives are identified by county of collection.

†Values for accessions of each species not followed by the same letter are different $(P \leq 0.05)$ by LSD Separation.

$\ddagger$ Source of accession may be incorrect.

$\S$ All accessions of purple needlegrass possessed dry, unfilled caryopses as early as Harvest 2 and appeared to be drought limited.

१Does not reflect prostrate growth form, which would increase the ratio. 
TABLE 2. Average 1994 production of 16 accessions of native perennial grass representing 4 species. Grasses were sampled in plantings at 2 locations, the UC Hopland Research and Extension Center in Mendocino County and Hedgerow Farms in Yolo County

\begin{tabular}{|c|c|c|}
\hline \multirow[b]{2}{*}{ Accession } & \multicolumn{2}{|c|}{$\begin{array}{l}\text { Forage production } \\
\text { Location }\end{array}$} \\
\hline & Hedgerow & Hopland \\
\hline $\begin{array}{l}\text { Blue wildrye } \\
\text { Santa Clara } \\
\text { Tehama } \\
\text { Marin }\end{array}$ & $\begin{array}{l}4,727 \mathrm{ab}^{*} \\
3,656 \text { cdefg } \\
3,641 \text { abcdef }\end{array}$ & $\begin{array}{l}\text { 4,587 abcd } \\
3,252 \text { efghij } \\
\text { 3,215 efghij }\end{array}$ \\
\hline $\begin{array}{l}\text { California melic } \\
\text { Lake } \\
\text { Yolo } \\
\text { Tehama }\end{array}$ & $\begin{array}{l}4,289 \text { abcde } \\
3,479 \text { defg } \\
3,171 \text { efghij }\end{array}$ & $\begin{array}{l}3,234 \text { efghij } \\
1,940 \mathrm{k} \\
2,146 \mathrm{jk}\end{array}$ \\
\hline $\begin{array}{l}\text { Nodding needlegrass } \\
\text { Solano } \\
\text { Kern } \\
\text { Yolo } \\
\text { Tehama }\end{array}$ & $\begin{array}{l}4,207 \text { abcd } \\
3,693 \text { cdefg } \\
3,646 \text { abcdef } \\
3,251 \text { defg }\end{array}$ & $\begin{array}{l}3,303 \text { efghi } \\
3,349 \text { efghi } \\
3,369 \text { efghi } \\
2,296 \text { ijk }\end{array}$ \\
\hline $\begin{array}{l}\text { Purple needlegrass } \\
\text { Yolo } \\
\text { Colusa } \\
\text { Tehama } \\
\text { Marin } \\
\text { Solano } \\
\text { Lake }\end{array}$ & $\begin{array}{l}4,748 \text { ab } \\
4,657 \text { abc } \\
4,249 \text { abcd } \\
3,916 \text { abcde } \\
3,532 \text { cdef } \\
3,140 \text { cdefgh }\end{array}$ & $\begin{array}{l}3,536 \text { bcdef } \\
4,062 \text { abcde } \\
3,166 \text { efghij } \\
2,250 \text { jk } \\
2,481 \text { ghijk } \\
2,380 \text { hijk }\end{array}$ \\
\hline $\begin{array}{l}\text { Orchard grass } \\
\text { (comparison species) } \\
\text { Berber }\end{array}$ & $5,135 \mathrm{a}$ & 2,871 fghijk \\
\hline
\end{tabular}

"Values not followed by the same letter are different $(P \leq 0.05)$ by LSD Separation using the square root transformation. Some apparent differences are not significant when the results are applied to original values.

TABLE 4. Average 1994 percent acid detergent fiber in 16 accessions of native perennial grass representing 4 species. Grasses were sampled in plantings at 2 locations, the UC Hopland Research and Extension Center in Mendocino County and Hedgerow Farms in Yolo County.

\begin{tabular}{|c|c|c|}
\hline \multirow[b]{2}{*}{ Accession } & \multicolumn{2}{|c|}{$\begin{array}{l}\text { Acid detergent fiber } \\
\text { Location }\end{array}$} \\
\hline & Hedgerow & Hopland \\
\hline $\begin{array}{l}\text { Blue wildrye } \\
\text { Tehama } \\
\text { Santa Clara } \\
\text { Marin }\end{array}$ & $\begin{array}{l}34.6 \mathrm{jklm}^{*} \\
34.1 \mathrm{Im} \\
33.8 \mathrm{~m}\end{array}$ & $\begin{array}{l}34.3 \mathrm{klm} \\
39.4 \mathrm{a} \\
38.6 \mathrm{ab}\end{array}$ \\
\hline $\begin{array}{l}\text { California melic } \\
\text { Lake } \\
\text { Yolo } \\
\text { Tehama }\end{array}$ & $\begin{array}{l}35.0 \text { hijklm } \\
34.8 \mathrm{ijkIm} \\
31.6 \mathrm{n}\end{array}$ & $\begin{array}{l}35.7 \text { fghijk } \\
36.1 \text { efghi } \\
31.8 n\end{array}$ \\
\hline $\begin{array}{l}\text { Nodding needlegrass } \\
\text { Kern } \\
\text { Tehama } \\
\text { Yolo } \\
\text { Solano }\end{array}$ & $\begin{array}{l}38.2 \text { abc } \\
38.2 \text { abc } \\
37.5 \text { bcde } \\
36.1 \text { efghi }\end{array}$ & $\begin{array}{l}37.4 \text { bcde } \\
36.4 \text { efgh } \\
36.9 \text { cdef } \\
36.6 \text { defg }\end{array}$ \\
\hline $\begin{array}{l}\text { Purple needlegrass } \\
\text { Yolo } \\
\text { Colusa } \\
\text { Tehama } \\
\text { Solano } \\
\text { Lake } \\
\text { Marin }\end{array}$ & $\begin{array}{l}39.2 \text { a } \\
38.1 \text { abcd } \\
36.9 \text { cdefg } \\
36.6 \text { efg } \\
36.2 \text { efghi } \\
35.5 \text { ghijkl }\end{array}$ & $\begin{array}{l}38.2 \mathrm{abc} \\
38.4 \mathrm{ab} \\
36.7 \mathrm{defg} \\
35.9 \mathrm{fghij} \\
38.2 \mathrm{abc} \\
34.3 \mathrm{kIm}\end{array}$ \\
\hline $\begin{array}{l}\text { Orchard grass } \\
\text { (comparison species) } \\
\text { Berber }\end{array}$ & $34.4 \mathrm{klm}$ & $34.5 \mathrm{jklm}$ \\
\hline
\end{tabular}

"Values not followed by the same letter are different $(P \leq 0.01)$ by LSD Separation.
TABLE 3. Average 1994 percent crude protein in 16 accessions of native perennial grass representing 4 species. Grasses were sampled in plantings at 2 locations, the UC Hopland Research and Extension Center in Mendocino County and Hedgerow Farms in Yolo County

\begin{tabular}{|c|c|c|}
\hline \multirow[b]{2}{*}{ Accession } & \multicolumn{2}{|c|}{$\begin{array}{l}\text { Crude protein } \\
\text { Location }\end{array}$} \\
\hline & Hedgerow & Hopland \\
\hline $\begin{array}{l}\text { Blue wildrye } \\
\text { Tehama } \\
\text { Santa Clara } \\
\text { Marin }\end{array}$ & $\begin{array}{l}12.7 \text { abcdef* } \\
10.6 \text { abcdef } \\
9.9 \text { bcdefghi }\end{array}$ & $\begin{array}{l}8.8 \text { hijklm } \\
6.5 \mathrm{n} \\
7.8 \mathrm{Imn}\end{array}$ \\
\hline $\begin{array}{l}\text { California melic } \\
\text { Tehama } \\
\text { Lake } \\
\text { Yolo }\end{array}$ & $\begin{array}{l}12.7 \text { abcdef } \\
11.9 \text { bcdefghi } \\
11.0 \text { defghijk }\end{array}$ & $\begin{array}{l}10.7 \text { abcdefgh } \\
8.5 \mathrm{jklm} \\
8.2 \mathrm{jklm}\end{array}$ \\
\hline $\begin{array}{l}\text { Nodding needlegrass } \\
\text { Solano } \\
\text { Kern } \\
\text { Tehama } \\
\text { Yolo }\end{array}$ & $\begin{array}{l}11.5 \mathrm{a} \\
10.7 \mathrm{abcdefg} \\
10.6 \text { abcde } \\
10.6 \text { abcdef }\end{array}$ & $\begin{array}{l}7.7 \mathrm{klmn} \\
8.6 \mathrm{jjklm} \\
8.8 \mathrm{fghijkl} \\
8.5 \mathrm{ijklm}\end{array}$ \\
\hline $\begin{array}{l}\text { Purple needlegrass } \\
\text { Solano } \\
\text { Marin } \\
\text { Tehama } \\
\text { Lake } \\
\text { Colusa } \\
\text { Yolo }\end{array}$ & $\begin{array}{l}11.3 \mathrm{abc} \\
11.2 \mathrm{ab} \\
11.1 \mathrm{abcd} \\
10.8 \mathrm{abcdef} \\
10.3 \mathrm{abcdefghi} \\
9.1 \text { ghijklm }\end{array}$ & $\begin{array}{l}9.1 \text { efghijk } \\
8.9 \mathrm{fghijkl} \\
8.0 \mathrm{jkIm} \\
7.3 \mathrm{mn} \\
7.2 \mathrm{mn} \\
7.3 \mathrm{mn}\end{array}$ \\
\hline $\begin{array}{l}\text { Orchard grass } \\
\text { (comparison species) } \\
\text { Berber }\end{array}$ & 9.9 cdefghij & $7.5 \mathrm{mn}$ \\
\hline
\end{tabular}

"Values not followed by the same letter are different $(P \leq 0.01)$ by LSD Separation using values transformed by rank.

TABLE 5. Average 1994 percent neutral detergent fiber in 16 accessions of native perennial grass representing 4 species. Grasses were sampled in plantings at 2 locations, the UC Hopland Research and Extension Center in Mendocino County and Hedgerow Farms in Yolo County

\begin{tabular}{|c|c|c|}
\hline \multirow[b]{2}{*}{ Accession } & \multicolumn{2}{|c|}{$\begin{array}{l}\text { Neutral detergent fiber } \\
\text { Location }\end{array}$} \\
\hline & Hedgerow & Hopland \\
\hline \multicolumn{3}{|l|}{ Blue wildrye } \\
\hline Tehama & $67.7 \mathrm{Im} *$ & $67.0 \mathrm{mn}$ \\
\hline Santa Clara & $63.7 \mathrm{opq}$ & $69.9 \mathrm{jkl}$ \\
\hline Marin & $62.4 \mathrm{pq}$ & $71.1 \mathrm{hij}$ \\
\hline \multicolumn{3}{|l|}{ California melic } \\
\hline Yolo & $68.0 \mathrm{klm}$ & $70.4 \mathrm{ijkl}$ \\
\hline Lake & $67.9 \mathrm{klm}$ & 70.4 hijk \\
\hline Tehama & 64.6 nop & $67.9 \mathrm{klm}$ \\
\hline \multicolumn{3}{|l|}{ Nodding needlegrass } \\
\hline Kern & 73.1 defgh & 75.3 bcde \\
\hline Tehama & 72.7 efghi & 74.6 cdef \\
\hline Yolo & 72.1 fghij & 74.3 cdefg \\
\hline Solano & 71.4 hij & 74.6 cdef \\
\hline \multicolumn{3}{|l|}{ Purple needlegrass } \\
\hline Yolo & 75.7 bcd & $79.1 \mathrm{a}$ \\
\hline Colusa & 72.8 efghi & $76.6 \mathrm{abc}$ \\
\hline Marin & 72.1 fghij & 72.7 efghi \\
\hline Solano & $71.6 \mathrm{ghij}$ & 75.5 bcd \\
\hline Tehama & 71.5 hij & $77.7 \mathrm{ab}$ \\
\hline Lake & $71.5 \mathrm{hij}$ & $76.1 \mathrm{bc}$ \\
\hline \multicolumn{3}{|l|}{$\begin{array}{l}\text { Orchard grass } \\
\text { (comparison species) }\end{array}$} \\
\hline Berber & $61.3 q$ & $65.3 \mathrm{mno}$ \\
\hline
\end{tabular}


At both sites, succeeding harvests of orchard grass were each lower. In the last harvest, there was no difference between sites, and PCP averaged $4 \%$. At Hedgerow, Berber was not different from any other accession in the last harvest. However, at Hopland it was lower than the average for Solano purple needlegrass and Tehama California melic (3.5\% vs. $5 \%$ ) but higher than Santa Clara blue wildrye $(2.1 \%)$.

Percentage acid detergent fiber (ADF). Berber's performance was not different at the two sites, but at Hedgerow its ADF content averaged $8 \%$ lower than that of all needlegrass except from Marin County (table 4). Orchard grass at this site was not different from any blue wildrye accession and different only from Tehama California melic, which was $8 \%$ lower.

At Hopland, orchard grass was lower in ADF than 11 of the native accessions: $8 \%$ lower than all needlegrasses except the two purple needlegrasses from Marin and Solano counties; more than $10 \%$ lower than two of the three blue wildryes (except the Tehama County accession); not different from Lake County California melic; and 9\% higher than Tehama California melic.

In each succeeding harvest, Berber's ADF was higher, and in the last harvest it did not differ between sites. In harvest 3 at Hopland, no accession was lower than Berber in ADF, and Tehama California melic and blue wildrye, and Solano purple needlegrass were not different. In the last harvest at Hedgerow, fewer accessions were different from Berber. At this site, Tehama blue wildrye was higher in ADF, and Tehama California melic was lower. Two accessions each of the needlegrasses were higher in ADF at Hedgerow: Kern and Tehama nodding needlegrass and Colusa and Yolo purple needlegrass.

Percentage neutral detergent fiber (NDF). At both sites, NDF in all but two native accessions was higher than that of Berber (table 5). At Hopland, Tehama blue wildrye and California melic were not different. For all others, average NDF was more than $14 \%$ higher. At Hedgerow, only
Santa Clara and Marin county blue wildryes were not different from Berber. The average NDF for all other accessions at this site was more than $15 \%$ higher.

Between harvests 2 and 3, Berber increased in NDF only at Hedgerow. In the last harvest at this site, Berber was lower in NDF than all except Marin and Santa Clara blue wildryes and Tehama California melic. In harvest 3 at Hopland, Berber was 15\% lower in NDF than the average of all native accessions.

\section{Genetic differences of grasses}

Because of the conservative analytical approach used in this study, we believe the results suggest strongly that there are genetic differences among the accessions observed. Other studies have shown that geographically separated grass populations can exhibit genetic differentiation (Clary 1975; Rice and Mack 1991).

In a study of purple needlegrass, Knapp and Rice (1998) showed that this species demonstrated regional differentiation for both isozymes and quantitative traits, but the patterns of variation were dissimilar; and among quantitative traits, variation was strongly associated with climate. These authors suggest that quantitative traits may be the most useful for differentiating among populations when evaluating plant material for restoration or reintroduction. But in the absence of information on quantitative trait variation, it would be wise to use material from a region where the climate is similar to that of the site being planted.

For the majority of the accessions we examined, forage production between sites remained unchanged. But in all species except blue wildrye, there were accessions that produced significantly less at Hopland as did Berber orchard grass. With respect to quality parameters, all but three accessions were lower in PCP at Hopland. Those not different at the two sites were California melics from two counties and one accession of purple needlegrass. Only four accessions showed a difference in ADF between sites; two of blue wildrye and one of purple needlegrass were higher at Hopland and one of nodding needlegrass was higher at Hedgerow. At Hopland, conditions increased NDF content in all but two accessions, one each of blue wildrye and purple needlegrass.

Between sites in our study, no one accession demonstrated consistent differences in quantitative traits. However, the differences in performance between accessions of the same species and the differences in response to site conditions strongly suggest the existence of geographic races among the accessions we evaluated. This supports the conclusions of Knapp and Rice (1998).

Where grasslands are used extensively, such as for grazing livestock, manipulation of forage composition is usually based on nutritional considerations and the desire to provide betterquality forage than that of resident annuals. In composite samples of annual range forage collected along a northsouth transect in the Central Valley, Hart et al. (1932) measured PCP, which declined from an average of more than $20 \%$ early in the growing season to values at maturity that ranged from averages of $10 \%$ or more in the northern part to less than $10 \%$ in the central and southern parts. In contrast, percentage crude fiber (approximately equal to percentage NDF) for selected annual grasses increased from an average of less than $25 \%$ early in the season to averages of more than $25 \%$ at flowering and $30 \%$ or more at maturity (Gordon and Sampson 1939; Hart et al. 1932).

\section{Annuals vs. perennials}

When resident annual grasses are compared with the native perennials in our study, neither group has an advantage with respect to protein content. However, the perennial grasses we measured are markedly higher in fiber (percentage NDF compared with percentage crude fiber) throughout the season. At the San Joaquin Experimental Range in Madera County, Green and Bentley (1957) observed that both purple and nodding needlegrass, 
which begin growth in the fall-winter period and can retain green tissue through summer (Laude 1953), were grazed closely by cattle when other green forage was limited. These grasses were avoided during spring when annual plant herbage was abundant. Early in the season, blue wildrye is also eaten with relish by all classes of livestock (Sampson et al. 1951) and this species will remain green and growing through the summer when adequately watered (Laude 1953). California melic also can retain green tissue through the summer (Laude 1953) and attracts season-long grazing by cattle (Sampson et al. 1951). In general, perennial grasses provide a longer green-feed period, with its associated nutritional value, compared with annuals (\$- mpson et al. 1951).

Perennial grasses represent a potential for more consistent erosion control than annual grasses. Talbot et al. (1939) reported fluctuations in annual grass populations that were extreme. Established perennial grasses produce biomass more consistently (Sampson et al. 1951) due to their growth habit and ability to access soil water at greater depths.

Root production and other factors determine the effectiveness of plants for erosion control. One of the most important of these is the ability to provide complete soil protection

(Goldman et al. 1986). In this respect, perennial grasses have an advantage. Compared with annual grasses, the vertical distribution of aboveground biomass is more nonlinear in perennials, and the percentage decreases more rapidly with height (Sampson et al. 1951).

For the accessions in our study, we prepared an index of weight to height ratios using measurements made at Hedgerow. These are expressed in pounds of average seasonal forage produced per inch of mature height. The ratio distorts the relationship by presenting it as linear. However, it does permit gross comparisons among accessions and suggests which concentrate higher percentages of biomass closer to the ground.
Nearly two-thirds of the accessions (11) had ratios of 41 to 50 , including all nodding needlegrasses, four of six purple needlegrasses and all three California melics. Accessions of blue wildrye had ratios either larger or smaller. If it is assumed that the erosioncontrol value of an accession is positively related to its ratio, Santa Clara County blue wildrye and Berber orchard grass provide the most erosion control. These accessions had ratios 9 to 10 points higher than the mode. The intraspecific variability in the ratios is another suggestion of genetic differences among accessions.

\section{Choose seed carefully}

The differences found among accessions of the four important California native bunch grasses we examined strongly suggest the existence of geographic races. Accessions selected for mitigation, restoration (including erosion control) and range seeding should be chosen carefully to avoid contamination of relict gene pools. Phenological differences suggest that matching reproductive cycles to local climates may be necessary to insure the persistence of seedings.

When seeding rangelands, resource managers should be aware of the potential impact on the health and nutrition of range livestock and wild herbivores. Native perennial grasses vary in quality and forage value, which have economic implications. Adaptation, use and economics should all be considered when planning to seed with native grasses.

T.E. Adams is Extension Wildlands Specialist, Emeritus, and P.B. Sands is Staff Research Associate (retired), Department of Agronomy and Range Science, UC Davis; C.E. Vaughn is Staff Research Associate, UC Hopland Research and Extension Center.

Partial support for this research was provided by the Extension Range Program and the Forage Quality Laboratory, Department of Agronomy and Range Science, UC Davis; UC Hopland Research and Extension Center (HOPLAND Grant No. 38-92); and Hedgerow Farms, Winters, Calif.
A more extensive analysis and discussion of the differences in Tables 2 to 5 is available from the senior author as a supplement to this article.

\section{References}

Clary WP. 1975. Ecotypic adaptation in Sitanion hystrix. Ecology 56:1407-15.

Dassman R. 1973. The Destruction of California. New York: Collier MacMillan Publishers. $223 \mathrm{p}$.

Fenster CB, Dudash MR. 1994. Genetic considerations for plant population restoration and conservation. In: Bowles ML, Whelan CJ (eds.). Restoration of Endangered Species. Cambridge, UK: Cambridge University Press. p 34-62.

Goldman SJ, Jackson K, Bursztynsky TA. 1986. Erosion and Sediment Control Handbook. New York: McGraw-Hill Book Co. $364 \mathrm{p}$.

Gordon A, Sampson AW. 1939. Composition of common California foothill plants as a factor in range management. Bulletin 627, UC Agric Exp Sta 95 p.

Green LR, Bentley JR. 1957. Seeding and grazing trials of stipa on foothill ranges. Forest Research Notes No. 127. Berkeley, $\mathrm{CA}$ : California Forest and Range Experiment Station, Forest Service, USDA. 9 p.

Hart GH, Guilbert HR, Goss H. 1932. Seasonal changes in the chemical composition of range forage and their relation to nutrition of animals. Bulletin 543, UC Agric Exp Sta $62 p$.

Knapp EE, Dyer AR. 1997. When do genetic considerations require special approaches to ecological restoration? In: Fiedler $\mathrm{P}$, Kareiva $\mathrm{P}$ (eds.). Conservation Biology for the Coming Decade. New York: Chapman and Hall. p 345-63.

Knapp EE, Rice KJ. 1998. Comparison of isozymes and quantitative traits for evaluating patterns of genetic variation in purple needlegrass (Nassella pulchra) Conserv Biol 12:1031-41.

Laude HM. 1953. The nature of summer dormancy in perennial grasses. Botanical Gazette 114:284-92.

Menke JW. 1989. Management controls on productivity. In: Huenneke LF, Mooney $\mathrm{H}$ (eds.). Grassland Structure and Function: California Annual Grassland. Dordrecht, Netherlands: Kluwer Academic Publishers. p 173-99.

Millar Cl, Libby WJ. 1989. Disneyland or native ecosystem: genetics and the restorationist. Restoration and Management Notes 7:18-24.

Rice KJ, Mack RN. 1991. Ecological genetics of Bromus tectorum III. The demography of reciprocally sown populations.

Oecologia 88:91-101.

Sampson AW, Chase A, Hedrick DW. 1951. California grasslands and range forage plants. Bulletin 724, UC Agric Exp Sta $130 \mathrm{p}$.

Talbot MW, Biswell HH, Hormay AL. 1939. Fluctuations in the annual vegetation of California. Ecology 20:394-402. 